CASSOWARY volume 4 (1): 28-38

ISSN : 2614-8900

E-ISSN : 2622-6545

Program Pascasarjana Universitas Papua, https://pasca.unipa.ac.id/

\title{
Pertumbuhan dan perkembangan Jamur Tiram Putih (Pleurotus ostreatus) pada media ampas Sagu
}

\author{
Choliq Kurniawan', Imam Widodo ${ }^{1}$, Barahima Abbas ${ }^{1,2 *}$ \\ ${ }^{1}$ Program Studi Agroteknologi, Fakultas Pertanian, Universitas Papua \\ ${ }^{2}$ Program Studi S2 Pertanian, Program Pascasarjana, Universitas Papua \\ Jalan Gunung Salju, Amban, Manokwari, Kodepos 98314, Papua Barat, Indonesia. \\ *Email: barahimabas@gmail.com
}

\begin{abstract}
White oyster mushroom (Pleurotus ostreatus) is currently quite popular and much loved by the public because of its delicious taste, high protein content, and low fat. This study aims to measuring the growth of white oyster mushrooms grown on sago dregs media with the treatment of various supplements, measuring the growth power of oyster mushrooms on sago dregs media with the treatment of various kinds of supplements, and measuring the production and efficiency of white oyster mushrooms on the substrate used. This research method consisted of 12 treatments and was repeated 3 times, so that there were 36 experimental units. Research Results White oyster mushrooms grown on MS2 media composition ( $20 \mathrm{~g}+\mathrm{MS} 80 \mathrm{ml}$ dry sago pulp) showed a good effect on mycelium growth and harvest rapidly. The highest number of fruit bodies was produced in the A3 treatment ( $20 \mathrm{~g}$ of dry sago pulp $+100 \mathrm{ml}$ of water). The highest body weight of fresh mushroom fruit was in the K3 treatment ( $20 \mathrm{~g}$ dry sago pulp +100 ml coconut water), KN3 (20 g dry sago pulp + $100 \mathrm{ml} \mathrm{KN}$ ), KN1 (20 g dry sago pulp + $60 \mathrm{ml} \mathrm{KN}$ ), and A3 (20 g of dry sago pulp $+100 \mathrm{ml}$ of water). The efficiency of utilization of sago waste organic matter by white oyster mushrooms was $25.84 \%$.
\end{abstract}

Keywords: sago dregs, oyster mushroom, media, nutrition, growth

\section{PENDAHULUAN}

Wilayah subtropis sampai kawa-san tropis tersebar ribuan spesies jamur. Jamur dapat bersifat merugikan dan menguntungkan. Jamur bersifat merugikan, yaitu jamur yang menyebabkan penyakit pada manusia dan tanaman, sedangkan jamur yang menguntungkan yaitu jamur yang bermanfaat bagi kehidupan, misalnya untuk menghancurkan sampah organik, menghasilkan antibiotik untuk obat, membuat tempe, oncom, maupun bahan makanan lain. Jamur sebagai bahan makanan adalah jamur yang dapat dikonsumsi, tanpa menimbulkan efek racun, misalnya: jamur kuping, jamur tiram, jamur merang, jamur shiitake, jamur champignon dan jamur barat (Parjimo dan Andoko 2007).

Jamur champignon dan shiitake hanya mampu tumbuh di tempat yang bersuhu rendah. Kedua jenis jamur tersebut dijual dengan harga mahal di Indonesia, sehingga daya beli masyarakat untuk kedua jenis jamur ini sangat rendah, dan menimbulkan kerugian bagi para petani jamur. Jamur kuping, jamur tiram dan jamur merang cocok dibudidayakan di Indonesia, baik ditinjau 
dari segi lingkungan maupun nilai keuntungan (Suriawiria 2002).

Jamur tiram putih (Pleurotus ostreatus) saat ini cukup populer dan banyak digemari oleh masyarakat karena rasanya yang lezat dan juga penuh kandungan nutrisi, tinggi protein, dan rendah lemak. Abbas et al. (2011) mempublikasikan bahwa jamur sagu memiliki nilai gizi yang tinggi, jamur sagu memiliki kandungan nutrisi per 100 gramnya adalah $4.00 \mathrm{~g}$ protein, $2.99 \mathrm{~g}$ karbohidrat, $0.19 \mathrm{~g}$ lemak, $11.53 \mathrm{mg}$ kalsium, $0.31 \mathrm{~g}$ fosfor, dan $165.05 \mathrm{mg}$ kalium. Jamur tiram putih mengandung protein, lemak, fosfor, besi, thiamin dan riboflavin lebih tinggi dibandingkan jenis jamur lain (Nunung, 2001). Widyastuti dan Istini (2004) melaporkan setiap 100 gram jamur tiram kering mengandung 7,8-17,72 g protein, 1-2,3 g lemak, 5,6-8,7 g serat kasar, $21 \mathrm{mg} \mathrm{Ca}$, $32 \mathrm{mg} \mathrm{Fe}, 0,21 \mathrm{mg}$ thiamin, 7,09 $\mathrm{mg}$ riboflavin, dan 57,6-81,8 g karbohidrat dengan 328-367 kcal energi. Jamur tiram berperan juga sebagai anti tumor, antioksidan, dan menurunkan kolesterol (Achmad et al., 2009). Jamur tiram mengandung $72 \%$ lemak yang merupakan asam lemak tidak jenuh, sehingga aman jika dikonsumsi bagi penderita kelebihan kolesterol maupun gangguan metabolisme lipid lainnya dan $28 \%$ nya adalah asam lemak jenuh yang membuat rasa jamur tiram enak (Prayoga, 2011).

Budidaya jamur tiram putih pada umumnya dilakukan dengan media limbah pertanian, terutama serbuk gergaji karena kandungan lignoselulosa yang tinggi. Riyati dan Sumarsih (2002), melakukan budidaya jamur tiram merah menggunakan sekam padi, ampas tebu, dan jerami padi sebagai media partumbuhan jamur tiram putih. Kemudian Riyati dan Sumarsih (2002), membandingkan ampas tebu dan limbah pabrik gula terhadap pertumbuhan dan produksi jamur tiram putih.
Industri pertanian dan perkebu-nan pada umumnya menghasilkan produk samping berupa limbah per-tanian, yang diperoleh setelah kegiatan pengolahan hasil panen. Limbah perta-nian dapat berwujud padat, cair dan gas. Salah satu limbah pertanian yang berwujud padat yaitu ampas sagu, yang diperoleh dari proses akhir panen pohon sagu (Metroxylon sagu)

\section{MATERI DAN METODE}

Bibit kultur jamur tiram putih pada fase F3 diperoleh dari CV. Volva Indonesia, Sleman, Yogyakarta. Sebelum bibit diinokulasikan pada substrat ampas sagu pada perlakuan media tanama, terlebih dahulu bibit diinokulasi menggunakan media MS dan substrat jagung. Inokulasi pada media MS bertujuan untuk menyegarkan bibit karena bibit berada pada kondisi yang telah lama disimpan, dan inokulasi pada substrat jagung sebagai substrak yang kaya energi. Ampas sagu yang diperoleh dari tempat pembuangan limbah ampas sagu masyarakat dikeringkan sampai mencapai berat konstan dengan menggunakan oven agar dapat dipastikan kadar air ampas sagu yang digunakan dapat dipastikan sesuai dengan perlakuan yang digunakan.

Ampas sagu yang telah dikering-kan selanjutnya ditimbang sebanyak 20 gram untuk setiap perlakuannya. Selan-jutnya ditambahkan air sesuai perlakuan yaitu sebanyak $60 \mathrm{ml}$ (A1), $80 \mathrm{ml}$ (A2) dan $100 \mathrm{ml}$ (A3) dan dicampur merata. Hal yang sama dilakukan pada perlakuan air kelapa $60 \mathrm{ml}$ (K1), $80 \mathrm{ml}$ (K2), $100 \mathrm{ml}$ (K3). Perlakuan berikutnya yaitu menggunakan larutan Murashige dan Skoog 1962 (MS) $60 \mathrm{ml}$ (MS1), $80 \mathrm{ml}$ (MS2) dan $100 \mathrm{ml}$ (MS3). Perlakuan terakhir yaitu menggunakan media Knudson C (KN) sebanyak $60 \mathrm{ml}(\mathrm{KN} 1)$, $80 \mathrm{ml}$ (KN2), dan $100 \mathrm{ml}$ (KN3). Pencampuran diusahakan tidak terdapat 
gumpalan, karena dapat mengakibatkan komposisi media yang diperoleh tidak merata. Setelah media selasai dicampur dengan perlakuan, maka selanjutnya untuk masing-masing perlakuan tersebut dimasukan ke dalam wadah botol kultur. Pengisian dilakukan dengan cara memasukan campuran bahan-bahan media tanam ke dalam botol kemudian dipadatkan, semakin padat akan semakin baik, karena akan memudahkan partumbuhan miselium dan tersedianya cadangan nutrisi dalam waktu yang lama. Selain itu, media yang kurang padat akan menyebabkan hasil panen tidak optimal karena kandungan nutrisi media cepat habis sehingga produktifitas menurun. Media yang jamur yang telah diisi pada wadah botol kultur ditutup rapat dengan menggunakan lembaran plastik dan ikat menggunakan karet gelang. Setiap botol kultur diberi label sesuai dengan perlakuan yang digunakan. Selanjutnya media disterilisasi sebelum diinokulasi dengan biakan jamur tiram.

Inokulasi merupakan proses penanaman bibit ke dalam media botol. Dilakukan dengan cara memindahkan bibit ke dalam botol sebanyak 1 sendok kecil (spatula), bibit yang digunakan adalah bibit yang sudah dikulturkan pada dimedia MS dan substrat jagung. Inokulasi dilakukan di dalam ruangan laminar air flow agar media tanam tidak terkontaminasi mikroorganisme yang tidak dikehendaki yang akan mengganggu pertumbuhan jamur tiram. Media yang telah diinokulasi kemudian disimpan di tempat yang tidak memiliki banyak cahaya, agar miselium jamur dapat tumbuh dengan baik. Inkubasi dilakukan dengan cara menyusun botol pada rak kultur. Lama waktu inkubasi lebih kurang 30 hari sampai media dipenuhi miselium. Inkubasi yang berhasil sudah bisa dilihat tanda-tandanya sekitar satu minggu setelah diinokulasi, yaitu tumbuhnya miselium jamur berwarna putih yang merambat pada substrat. Miselium akan tumbuh mulai dari bagian atas kemudian merambat ke seluruh permukan substrat yang digunakan sebagai media.

Pemanenan dilakukan $2-3$ hari setelah tumbuh jamur, dengan ciri-ciri: tudung telah mekar, warna belum pudar, tekstur masih kokoh dan lentur. Pada saat itu ukuran jamur sudah cukup besar. Pemanenan dilakukan pada sore hari. Pemanenan disini dilakukan dengan cara memotong pada bagian pangkal batang menggunakan gunting yang bersih. Data yang diperoleh dari penelitian ini dianalisis secara statistik dengan menggunakan sidik ragam (ANOVA). Perlakuan yang nilai ANOVA nya nyata dilanjutkan dengan uji BNT 5\%, menggunakan program CoStat 6.311.

\section{HASIL DAN PEMBAHASAN}

\section{Waktu Pertumbuhan Miselium}

Hasil analisis ragam menunjuk-kan pengaruh yang tidak nyata terhadap waktu munculnya miselium, tetapi berbeda nyata dengan waktu pemenuhan substract dengan miselium. Nilai ratarata pengukuran respon perlakuan disajikan pada Tabel 1.

Data pada Tabel 1 menunjukkan bahwa waktu tumbuhnya miselium pada keseluruhan perlakuan menunjukkan pengaruh yang tidak nyata. Perlakuan $\mathrm{A} 3, \mathrm{~K} 2, \mathrm{~K} 3, \mathrm{MS} 2, \mathrm{MS} 3$, dan $\mathrm{KN} 3$ menunjukkan pertumbuhan miselium tercepat dengan rata-rata 2 hari setelah inokulasi. Penampilan miselium yang baru mulai tumbuh disajikan pada Gambar 1. 
Tabel 1. Nilai rata-rata waktu pertumbuhan miselium (hari), lama penyebaran miselium (hari), waktu pertumbuhan primordia (hari)

\begin{tabular}{llll}
\hline Perlakuan & $\begin{array}{l}\text { Waktu Tumbuh } \\
\text { Miselium (Hari) }\end{array}$ & $\begin{array}{l}\text { Waktu Penyebaran } \\
\text { Miselium (Hari) }\end{array}$ & $\begin{array}{l}\text { Waktu Tumbuh } \\
\text { Primordia (Hari) }\end{array}$ \\
\hline A1 & 2,33 & $13,67 \mathrm{a}$ & $48,33 \mathrm{~b}$ \\
A2 & 2,67 & $14,00 \mathrm{a}$ & $48,00 \mathrm{~b}$ \\
A3 & 2,00 & $15,67 \mathrm{a}$ & $48,33 \mathrm{~b}$ \\
K1 & 2,33 & $25,00 \mathrm{~b}$ & $71,33 \mathrm{c}$ \\
K2 & 2,00 & $17,00 \mathrm{a}$ & $50,00 \mathrm{~b}$ \\
K3 & 2,00 & $17,33 \mathrm{a}$ & $46,67 \mathrm{~b}$ \\
MS1 & 2,33 & $13,33 \mathrm{a}$ & $47,00 \mathrm{~b}$ \\
MS2 & 2,00 & $12,00 \mathrm{a}$ & $33,00 \mathrm{a}$ \\
MS3 & 2,00 & $12,33 \mathrm{a}$ & $34,33 \mathrm{a}$ \\
KN1 & 2,33 & $12,00 \mathrm{a}$ & $49,67 \mathrm{~b}$ \\
KN2 & 2,33 & $12,00 \mathrm{a}$ & $50,00 \mathrm{~b}$ \\
KN3 & 2,00 & $14,00 \mathrm{a}$ & $55,00 \mathrm{~b}$ \\
\hline
\end{tabular}

Keterangan: Angka-angka yang diikuti dengan huruf yang sama pada kolom yang sama tidak berbeda nyata berdasarkan Uji BNT pada taraf 5\%. Waktu penyebaran miselium yaitu waktu yang diperlukan untuk memenuhi substrak dari masing-masing perlakuan.
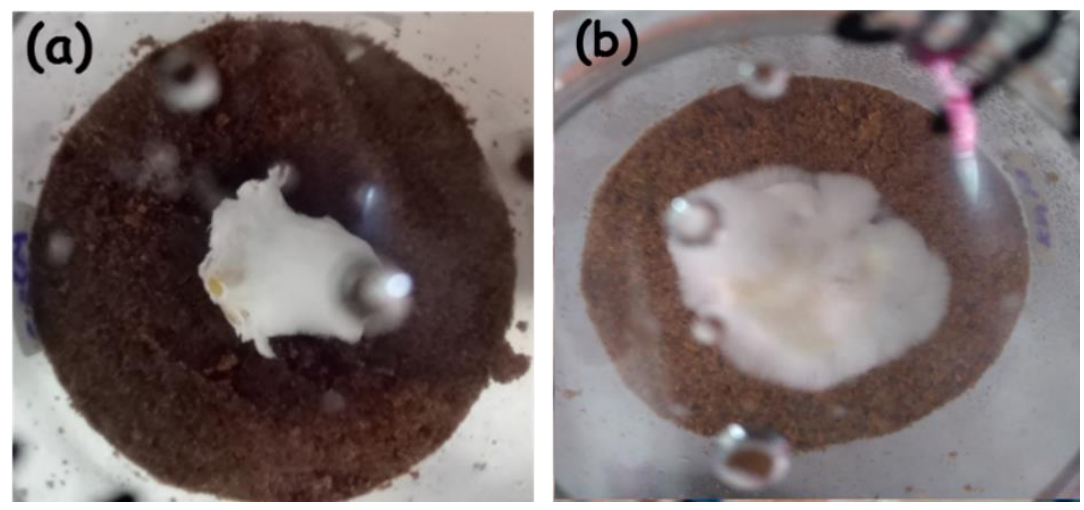

Gambar 1. Pertumbuhan dan perkembangan inokulum jamur tiram pada ampas sagu. Inokulum yang baru diinokulasi pada media ampas sagu (a), pertumbuhan miselium (b).

Perlakuan A3, K2, K3, MS2, MS3, dan KN3 juga menunjukkan pertumbuhan miselium yang cepat diduga disebabkan karena ampas sagu yang digunakan mampu menyedian $\mathrm{N}$, air kelapa, MS dan KN sendiri memiliki kandungan unsur hara $\mathrm{N}$ di dalamnya. Unsur hara $\mathrm{N}$ sangat dibutuhkan dalam pertumbuhan miselium. Hal ini sesuai dengan pendapat Suriawiria (2002) yang menyatakan bahwa kehidupan dan perkembangan miselium jamur tiram memerlukan media yang mengandung nitrogen, C-organik, karbohidrat, lignin dan beberapa zat lainnya. Winoto (1998) membuktikan dengan hasil analisisnya bahwa ampas sagu mengandung 53,20\% C-organik, $0,13 \%$ nitrogen dan $0,08 \%$ kalium.

Penambahan suplemen air kela-pa, MS, dan KN ke dalam media ampas sagu menyebabkan kandungan $\mathrm{N}$ dapat memenuhi kebutuhan pertumbuhan miselium. Menurut Nawaruddin et al., 
(2017) penambahan suplemen ke media ampas sagu menyebabkan kandungan $\mathrm{N}$ semakin tinggi dan rasio $\mathrm{C} / \mathrm{N}$ semakin rendah. Kandungan pati yang tinggi pada ampas sagu menyebabkan media menjadi lebih padat sehingga waktu tumbuh miselium jamur tiram terhambat. Jumantara (2011) menyatakan bahwa ampas sagu merupakan biomasa lignoselulosa yang mengandung komponen penting seperti pati sebanyak $64,6 \%$.

\section{Waktu Penyebaran Miselium (Hari)}

Hasil pengukuran pada Tabel 1 menunjukkan bahwa, komposisi media tanam berpengaruh nyata terhadap waktu penyebaran miselium pada substrat. Perlakuan MS2, KN1, dan KN2 menunjukkan rata-rata waktu penyebaran miselium tercepat dengan rata-rata waktu penyebaran 12 hari, sedangkan pada perlakuan K1 menunjukkan rata-rata waktu penyebaran miselium terlama dengan rata-rata waktu penyebaran 25 hari. Penampilan pertumbuhan miselium disajikan pada Gambar 2.

Penyebaran miselium diamati sejak miselium muncul. Hal ini dikarenakan miselium akan mudah berkembang dengan tersedianya bahan-bahan organik pada substrat. Jamur tiram menggunakan sumber karbon yang berasal dari bahan organik untuk diuraikan menjadi senyawa karbon sederhana kemudian diserap ke dalam miselium untuk perkembangan miselium (Djarijah dan Djarijah, 2001). Perlakuan MS2, KN1, dan $\mathrm{KN} 2$ cenderung mening-katkan daya tumbuh miselium. Hal ini diduga karena kandungan $\mathrm{N}$ pada media ampas sagu mencukupi akibat penam-bahan suplemen. Wijaya (2008) mengungkapkan bahwa ketersediaan unsur $\mathrm{N}$ dapat meningkatkan daya tumbuh miselium jamur tiram. Perlakuan K1 yang menunjukkan waktu terlama dalam penyebaran miselium, diduga disebabkan jumlah nutrisi yang terkandung dalam media yang diperkaya air kelapa menjadi inhibitor dalam pertumbuhan miselium. Yuniarti (2004) melaporkan bahwa kandungan nutrien dalam media tumbuh jamur umumnya terpenuhi, sehingga untuk media tertentu tidak perlu ditambahkan nutrisi.

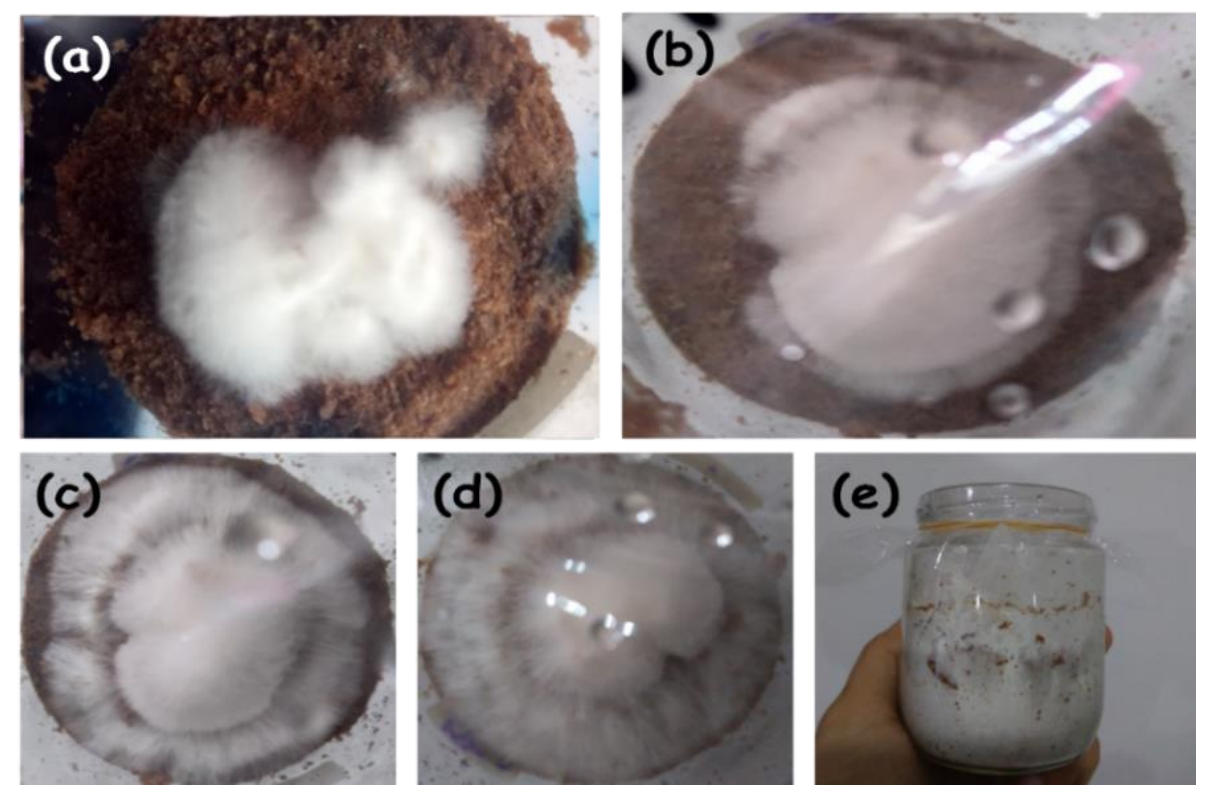

Gambar 2. Penyebaran miselium: 5\% (a), 20\% (b), 90\% (c), 100\% (d), dan memenuhi substrat (e). 

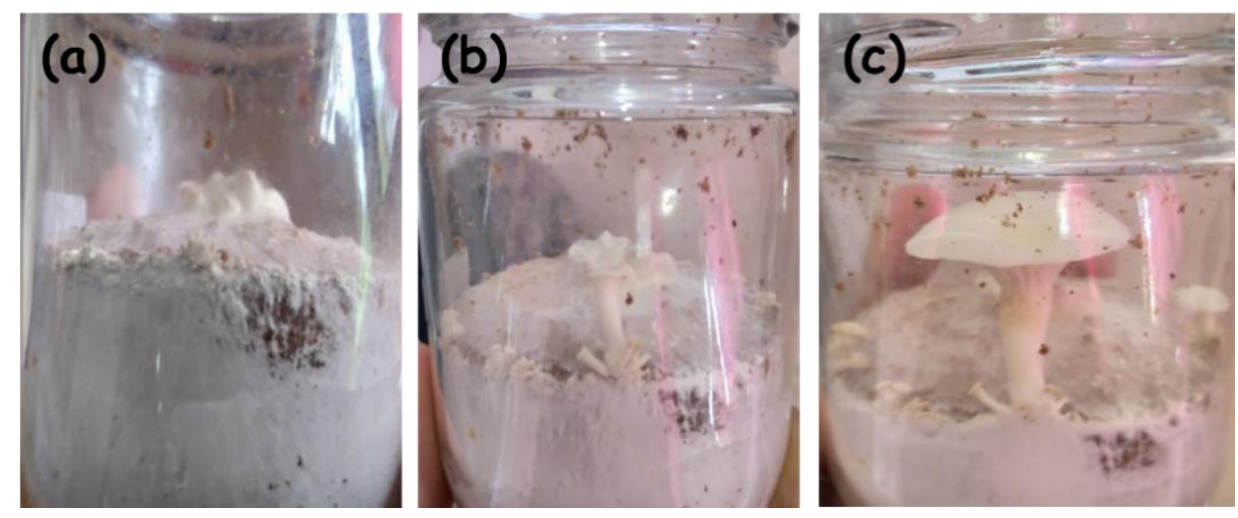

Gambar 3. Pertumbuhan dan perkembangan jamur tiram pada media ampas sagu.

Primordia tubuh buah (a), tubuh buah (b), dan tubuh buah siap panen (c).

\section{Waktu Pertumbuhan Primordia (Hari)}

Hasil analisis ragam menun-jukkan bahwa komposisi media tumbuh jamur tiram berpengaruh nyata. Nilai rata-rata waktu pertumbuhan primordia setelah dilakukan uji BNT disajikan pada Tabel 1. Komposisi media MS2 yaitu ampas sagu dan MS $80 \mathrm{ml}$ memiliki waktu pertumbuhan primordia tercepat dan berbeda nyata dibandingkan dengan $\mathrm{K} 1$ yang komposisinya ampas sagu dan air kelapa $60 \mathrm{ml}$. Hal ini diduga dise-babkan waktu pertumbuhan primordia berkaitan dengan waktu pertumbuhan miselium dan lama penyebaran miselium (Tabel 1). Komposisi media MS2 me-nginduksi pertumbuhan miselium yang lebih cepat dan selanjutnya berpengaruh pada pertumbuhan primordia jamur lebih cepat. Dugaan tersebut sesuai dengan yang dilaporkan Tutik (2004) bahwa pertumbuhan primordia jamur terbaik berhubungan dengan waktu tumbuh miselium karena terbentuknya primordia diawali dengan pertumbuhan miselium jamur.

Komposisi media K1 menyebab-kan pertumbuhan primordia lebih lama. Hal tersebut diduga air kelapa yang ditambahkan sebagai suplemen belum dapat menyediakan nutrisi seuai dengan kebutuhan jamur. Murbandono (2002) menyatakan bahwa jasad renik yang menguraikan senyawa-senyawa yang komplek menjadi senyawa yang lebih sederhana memerlukan senyawa yang mengandung unsur $\mathrm{N}$ sehingga semakin banyak kandungan $\mathrm{N}$ makin cepat pula proses dekomposisi.

\section{Pertumbuhan Tubuh Buah}

Hasil analisis ragam menun-jukkan pengaruh yang nyata terhadap umur panen jamur tiram. Nilai rata-rata dari hasil uji BNT umur panen jamur disajikan pada Tabel 2.

Perlakuan MS2 dan MS3 menunjukkan waktu panen tercepat yaitu 36,67 hari dan 37,67 hari, dan waktu umur panen terlama yaitu perlakuan K1 dengan rata-rata waktu 74,33 hari (Tabel 2). Penampilan saat panen disajikan pada Gambar 4.

Perlakuan MS2 (ampas sagu + MS 80 $\mathrm{ml}$ ) dan MS3 (ampas sagu + MS $100 \mathrm{ml}$ ) diduga memiliki kandungan unsur hara lebih terpenuhi dibandingkan perlakuan $\mathrm{K} 1$ (ampas sagu + air kelapa $60 \mathrm{ml}$ ), terutama unsur nitrogen. Nawa-ruddin et al., (2017) melaporkan bahwa kandungan nitrogen yang tinggi diperlukan untuk pertumbuhan miselium dan pembentukan badan buah jamur tiram putih. Komposisi media K1 waktu panennya lebih lama, diduga dengan tambahan $60 \mathrm{ml}$ air kelapa sebagai suplemen membuat media kelebihan 
hormon tumbuh yang berpengaruh negatif terhadap pertumbuhan primordia jamur tiram (Tabel 2) dan berpengaruh pada umur panen yang lebih lama. Zat pengatur tumbuh berpengaruh mendorong pertumbuhan pada konsentrasi yang sesuai dan menghambat pertumbuhan pada konsentrasi yang berlebih (Abidin, 2000).

\section{Jumlah Tubuh Buah per Botol (Buah)}

Hasil analisis ragam pada varia-bel jumlah tubuh buah menunjukkan pengaruh yang tidak nyata (Tabel 2). Perlakuan A3 menginduksi pertumbuhan tubuh buah dengan rata-rata 3,67 buah, sedangkan pada perlakuan K2, MS1, dan MS2 menginduksi pertumbuhan tubuh buah dengan rata-rata 1,00 buah.

Perlakuan A3 yang memperoleh ratarata jumlah tubuh buah terbanyak, hal ini diduga karena kandungan C-or-ganik pada ampas sagu sebesar 53,20\% dapat mendorong pertumbuhan badan buah jamur tiram putih. Seperti yang dilaporkan Nawaruddin et al., (2017) bahwa C-organik merupakan sumber energi untuk pertumbuhan miselium sampai terbentuknya primodia dan pertumbuhan tudung jamur maksimal. Perlakuan K2, MS1, dan MS2 menginduksi pertumbuhan tubuh buah paling sedikit. Faktor yang mempengaruhi jumlah tudung jamur adalah banyaknya jumlah primordia jamur (Sukahar, 1999). Menurut Oei (1996), jumlah primordia dipengaruhi oleh faktor lingkungan yaitu perubahan suhu, kelembaban, defisiensi nutrient, konsen-trasi $\mathrm{CO} 2$, dan konsentrasi $\mathrm{O}_{2}$. Penelitian sebelumnya mengungkapkan bahwa perkembangan primordia menjadi tubuh buah jamur tiram membutuhkan oksigen yang cukup (Nawaruddin et al., 2017).

Tabel 2. Nilai rata-rata umur panen (hari), jumlah tubuh buah (buah), berat tubuh buah jamur segar (g)

\begin{tabular}{cccc}
\hline Perlakuan & $\begin{array}{c}\text { Waktu Panen } \\
\text { (Hari) }\end{array}$ & $\begin{array}{c}\text { Jumlah Tubuh } \\
\text { Buah (Buah) }\end{array}$ & $\begin{array}{c}\text { Berat Tubuh Buah } \\
\text { Jamur Segar }(\mathbf{g})\end{array}$ \\
\hline A1 & $52,00 \mathrm{~b}$ & 2,67 & $3,02 \mathrm{bc}$ \\
A2 & $52,00 \mathrm{~b}$ & 2,33 & $3,09 \mathrm{bc}$ \\
A3 & $52,00 \mathrm{~b}$ & 3,67 & $3,51 \mathrm{abc}$ \\
K1 & $74,33 \mathrm{c}$ & 1,67 & $0,58 \mathrm{~d}$ \\
K2 & $53,67 \mathrm{~b}$ & 1,00 & $3,13 \mathrm{bc}$ \\
K3 & $51,00 \mathrm{~b}$ & 2,33 & $4,39 \mathrm{a}$ \\
MS1 & $51,00 \mathrm{~b}$ & 1,00 & $1,06 \mathrm{~d}$ \\
MS2 & $36,67 \mathrm{a}$ & 1,00 & $0,93 \mathrm{~d}$ \\
MS3 & $37,67 \mathrm{a}$ & 2,33 & $1,11 \mathrm{~d}$ \\
KN1 & $53,33 \mathrm{~b}$ & 2,33 & $3,92 \mathrm{ab}$ \\
KN2 & $53,67 \mathrm{~b}$ & 1,33 & $2,66 \mathrm{c}$ \\
KN3 & $58,67 \mathrm{~b}$ & 1,67 & $4,11 \mathrm{ab}$ \\
\hline
\end{tabular}

Keterangan: Angka-angka yang diikuti dengan huruf yang sama pada kolom yang sama tidak berbeda nyata berdasarkan Uji BNT pada taraf 5\%. 

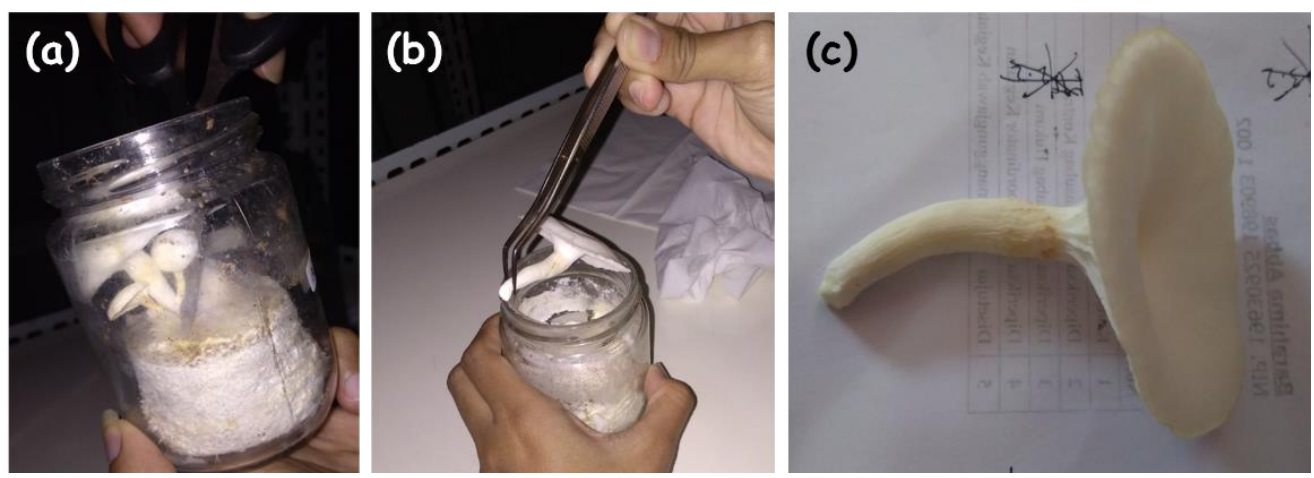

Gambar 4. Kegiatan saat panen. Memotong bagian pangkal tubuh buah (a), memisahkan dari media tumbuh (b), dan tubuh buah yang dipanen (c).
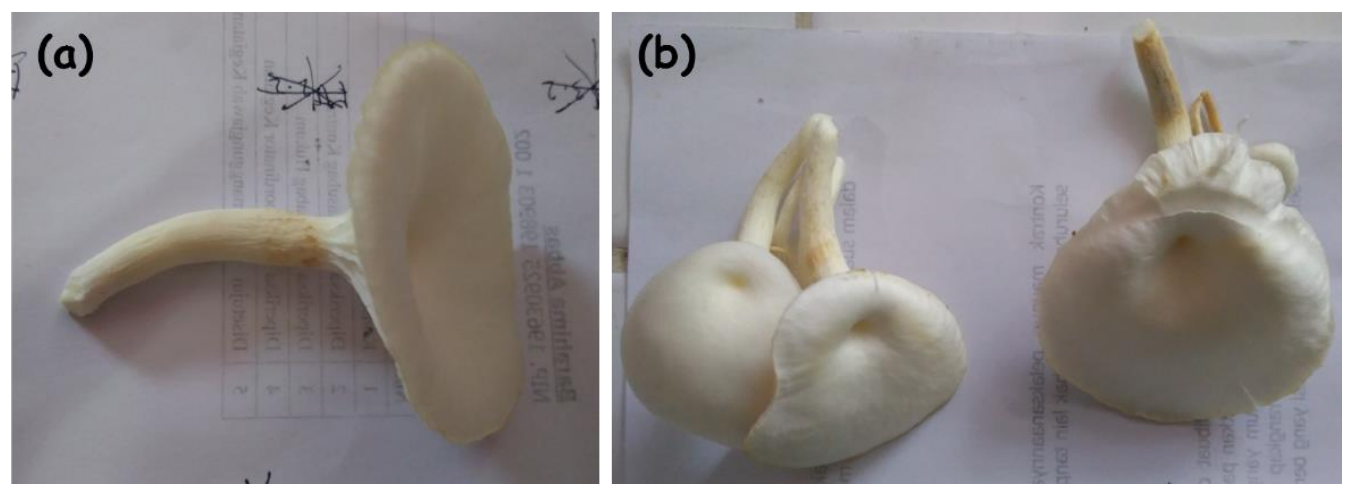

Gambar 5. Jumlah tubuh buah. 1 tubuh buah (a), dan lebih dari 1 tubuh buah (b).

\section{Berat Tubuh Buah Jamur Segar (gram)}

Hasil analisis ragam dan uji BNT pada Tabel 2 menunjukkan bahwa komposisi media tumbuh jamur tiram yang digu-nakan memberikan pengaruh nyata. Perlakuan K3 menginduksi pertumbuhan tubuh buah jamur dengan rata-rata 4,39 gram, sedang perlakuan K1 menginduksi pertumbuhan tubuh buah paling rendah yaitu 0,58 gram. Perlakuan K3 meng-induksi pertumbuhan tubuh buah dengan berat paling tinggi dibandingkan perla-kuan lainnya. Hal tersebut diduga karena berat tubuh buah segar berhubungan dengan jumlah tubuh buah per botol (Tabel 2). Hasil penelitian ini sejalan dengan yang diungkapkan oleh Nawa-ruddin et al., (2017) yang menyatakan bahwa jumlah tubuh buah yang ter-bentuk akan mempengaruhi berat basah tubuh buah jamur. Konsentrasi air kelapa yang diberikan ke media juga dapat mempengaruhi bobot segar jamur tiram. Sesuai dengan pernyataan Dalimunthe (2018), pemberian air kelapa dengan dosis yang tepat dan seimbang dapat mempengaruhi bobot segar jamur tiram. Menurut Netty dan Donowati (2007), bahwa pemberian air kelapa berpengaruh terhadap berat basah tubuh buah jamur, karena pada air kelapa memiliki kandungan hormon auksin dan sitokinin yang dapat mempengaruhi kualitas hasil panen salah satunya berat basah tubuh buah jamur. Auksin berfungsi membantu menaikkan kualitas hasil panen, memacu proses terbentuknya akar serta pertumbuhan akar dengan baik, merangsang dan mempertinggi timbulnya tubuh buah. menyatakan bahwa dengan penambahan nutrisi pada media tanam akan meningkatkan kemampuan jamur dalam 
penyerapan nutrisi dan dapat meningkatkan bobot dari jamur (Suriawiria 2002; Abbas and Listyorini, 2011). Tutik (2004) melaporkan bahwa nutrisi yang tersedia dalam media tanam yang mampu diserap oleh jamur akan mampu meningkatkan berat basah jamur tiram tersebut.

\section{Efisiensi Bahan Organik (\%)}

Hasil analisis ragam efisiensi pemanfaatan bahan organik menunjukkan pengaruh yang nyata terhadap perlakuan yang digunakan. Nilai ratarata dari hasil uji BNT terhadap efisiensi bahan organik di sajikan pada Tabel 3.

Tabel 3. Nilai rata-rata efisiensi bahan organik (\%)

\begin{tabular}{cc}
\hline Perlakuan & $\begin{array}{c}\text { Efisiensi Bahan } \\
\text { Organik }(\%)\end{array}$ \\
\hline A1 & $17,74 \mathrm{de}$ \\
A2 & $18,23 \mathrm{de}$ \\
A3 & $20,67 \mathrm{bcd}$ \\
K1 & $3,41 \mathrm{f}$ \\
K2 & $18,40 \mathrm{cde}$ \\
K3 & $25,84 \mathrm{a}$ \\
MS1 & $5,92 \mathrm{f}$ \\
MS2 & $5,49 \mathrm{f}$ \\
MS3 & $6,54 \mathrm{f}$ \\
KN1 & $23,06 \mathrm{abc}$ \\
KN2 & $15,68 \mathrm{e}$ \\
KN3 & $24,17 \mathrm{ab}$ \\
\hline
\end{tabular}

Keterangan: Angka-angka yang diikuti dengan huruf yang sama pada kolom yang sama tidak berbeda nyata berdasarkan Uji BNT pada taraf 5\%.

Perlakuan K3 mendorong pemanfaatan efisiensi bahan organik ampas sagu paling tinggi yaitu $25,84 \%$ dibandingkan dengan perlakuan lainnya, sedangkan pada perlakuan K1 pemanfaatan efisiensi bahan organik paling rendah yaitu hanya sebesar $3,41 \%$. Hal tersebut sejalan dengan hasil pengama- tan parameter berat tubuh buah segar yang juga menunjukkan bahwa komposisi media K3 cenderung lebih berat dibandingkan perlakuan lainnya.

Menurut FAO (1992) hasil produksi jamur tiram dari $4-5$ kali panen selama 4 bulan yaitu antara $30-45 \%$ dari berat media. Efisiensi peman-faatan bahan organik pada penelitian berkisar antara 3,41-25,84\%. Rendah-nya efisiensi bahan organik karena penelitian hanya dilakukan selama 3 bulan setelah inokulasi. Kemudian kondisi media setelah panen seharusnya masih mampu memproduksi lagi ditandai dengan adanya pertumbuhan primordia baru. Namun yang terjadi disaat setelah panen pertama, primordia yang baru muncul tersebut tidak dapat tumbuh dan berkembang karena umum-nya terjadi kontaminan pada media disaat panen pertama dilakukan.

Rendahnya efisiensi bahan organik yang dihasilkan juga dapat disebabkan karena kandungan selulosa dalam ampas sagu tergolong rendah. Menurut Jumantara (2011), ampas sagu mengandung residu lignin sebesar $21 \%$, sedangkan kandungan selulosa di dalamnya sebesar $20 \%$ dan sisanya merupakan zat ekstraktif dan abu. Kandungan dalam ampas sagu tersebut lebih rendah jika dibandingkan dengan serbuk kayu karet yang digunakan oleh Afief et al., (2015) dalam penelitiannya yang menggunakan serbuk kayu karet sebagai media tumbuh jamur tiram. Kayu karet sendiri memiliki komponen kimia berupa kadar selulosa sebesar 43,98\% dan kadar lignin sebesar 26,39\% (Safitri, 2003). Hal ini sesuai dengan pernyataan Stevanie (2011) yang menyatakan bahwa bahan organik yang mengandung selulosa dan lignin dalam jumlah besar akan mendukung partumbuhan miselium dan perkembangan tubuh buah. 


\section{KESIMPULAN}

Hasil penelitian yang telah dilakukan dapat disimpulkan bahwa jamur tiram putih yang ditumbuhkan pada media ampas sagu dengan perlakuan berbagai macam suplemen dapat tumbuh membentuk miselium dan daya tumbuh miselium pada tiap-tiap perlakuan berbeda-beda. Jamur tiram putih yang ditumbuhkan pada komposisi media MS2 (ampas sagu kering $20 \mathrm{~g}+\mathrm{MS} 80$ $\mathrm{ml}$ ) menunjukkan pengaruh yang baik terhadap waktu pertumbuhan miselium, waktu panen. Jumlah tubuh buah yang dihasilkan terbanyak pada perlakuan A3 (ampas sagu kering $20 \mathrm{~g}+$ air $100 \mathrm{ml}$ ). Berat tubuh buah jamur segar yang dihasilkan paling tinggi pada perlakuan K3 (ampas sagu kering $20 \mathrm{~g}+$ air kelapa $100 \mathrm{ml}$ ), KN3 (ampas sagu kering $20 \mathrm{~g}+$ $\mathrm{KN} 100 \mathrm{ml}$ ), KN1 (ampas sagu kering 20 $\mathrm{g}+\mathrm{KN} 60 \mathrm{ml}$ ), dan A3 (ampas sagu kering $20 \mathrm{~g}+$ air $100 \mathrm{ml}$ ). Efisiensi pemanfaatan bahan organik ampas sagu oleh jamur tiram putih sebesar $25,84 \%$.

\section{UCAPAN TERIMA KASIH}

Penelitian ini dibiayai oleh Proyek Penelitian Riset Pengembangan yang berjudul "Transformasi invensi berbasis sagu menjadi inovasi yang berorientasi entrepreneurship dalam rangka mengakselerasi daya saing dan kemandirian Bangsa dibidang pangan" dengan kontrak No. 198/SP2H/AMD/ LT/DRPM/2020. Kepada Pengelola Riset Pengembangan Kementerian Riset, Tek-nologi dan Pendidikan Tinggi diucapkan terima kasih. Ucapan terima kasih juga disampaikan kepada Ketua Peneliti dan Anggota Peneliti Skim Penelitian Riset Pengembangan yang telah memberikan kesempatan dan melibatkan dalam penelitian tersebut.

\section{DAFTAR PUSTAKA}

Abbas B, F. H. Listyorini. 2010. Pertumbuhan dan Perkembangan Biakan Semai Jamur Sagu (Volvariella sp.) Membentuk Tubuh Buah pada Berbagai Macam Media Tumbuh. Jurnal Agrotek 2 (1):6-12

Abbas B, F. H. Listyorini, E A. Martanto. 2011. Karakteristik jamur sagu (Volvariella sp.) Endemik Papua. Jurnal Natur Indonesia 13(2):168-173

Abidin. 2000. Dasar-Dasar Zat Pengatur Tumbuh. Angkasa Raya, Bandung.

Achmad, H. E. N., O. A. F. Yurti, dan A. P. Hidayat. 2009. Karakterisitik Fisiologi Isolat Plurotus spp. Jurnal Littri. 15(1): 46-51.

Afief, M. F., R. L. Ratna, dan S. Balonggu. 2015. Respon Pertumbuhan dan Produksi Jamur Tiram Putih (Pleurotus ostreatus) terhadap Berbagai Media Serbuk Kayu dan Pemberian Pupuk NPK. Jurnal Online Agroteknologi. Medan (3)4: 1381-1390.

Dalimunthe, D. 2018. Pengaruh Pemberian Air Kelapa terhadap Pertumbuhan dan Produksi Jamur Tiram (Pleurotus ostreatus). Skripsi. Universitas Muhammadiyah Sumatera Utara. Medan.

Djarijah, N. M dan A. S. Djarijah. 2001. Budidaya Jamur Tiram. Kanisius, Yogyakarta.

FAO. 1992. Food and Agriculture Organization of United Nation. Content of Oyster Mushroom.

Murbandono L. 2002. Membuat Kompos. Edisi Revisi. Penebar Swadaya. Jakarta.

Nawaruddin. Murniati, dan F. Silvina. 2017. Penggunaan Serbuk Gergaji dan Ampas Sagu dengan 
Beberapa Komposisi sebagai Media Tumbuh Jamur Tiram Putih (Pleurotus ostreatus Jacq.). JOM Faperta 4(1): 1-11.

Netty, W dan T. Donowati. 2007. Peranan Beberapa Zat pengatur Tumbuh (ZPT) Tanaman pada Kultur In Vitro. Jurnal Sains dan Teknologi Indonesia. 3(5): 5563.

Nunung, M. D. 2001. Budidaya Jamur Tiram. Kanisius, Yogyakarta.

Oei, B. $1996 . \quad$ Mushroom Cultivation.Technical Center for Agriculture and Rural Cooperation. Tool Publications, Leiden, Netherlands.

Parjimo dan A. Andoko. 2007. Budidaya Jamur. Agromedia Pustaka, Jakarta.

Prayoga, A. 2011. Sukses Budidaya Nilai Tumpangsari Jamur Tiram. Abata Press, Klaten.

Riyati, R dan S. Sumarsih. 2002. Pengaruh Perbandingan Bagas dan Blotong terhadap Pertumbuhan dan Produksi Jamur Tiram Putih (Pleurotus ostreatus). Agrivet. Yogyakarta.

Safitri, E. S. 2003. Analisis Komponen Kimia dan Dimensi Serat Kayu Karet (Hevea brasiliensis Muell. Arg.) Hasil Klon. Skripsi. Fakultas Teknologi Hasil Hutan, Institut Pertanian Bogor. Bogor.

Sukahar, A. 1999. Pengaruh Kandungan Bungkil Kelapa pada Media Serbuk Gergaji Kayu Alba terhadap Produksi Jamur Tiram
Putih (Pleurotus ostreatus). Skripsi. FMIPA Biologi. UNDIP. Semarang

Suriawiria, U. 2002. Budidaya Jamur Tiram. Kanisius, Yogyakarta.

Tutik. L. A. 2004. Penambahan Tongkol Jagung dan Tetes Tebu pada Media Serbuk Gergaji terhadap Pertumbuhan Jamur Kuping. Skripsi. Fakultas Pertanian UMM. Malang.

Widyastuti, N dan S. Istini. 2004. Optimasi Proses Pengeringan Tepung Jamur Tiram Putih (Pleurotus ostreatus). BPPT.

Wijaya, B. 2008. Budidaya Jamur Kompos, Jamur Merang, Jamur Kancing. Penebar Swadaya, Jakarta.

Winoto. 1998. Pemanfaatan Limbah Sagu (Metroxylon sagu Rottb.) sebagai Media Tanam pada Pembibitan Tanaman Sengon (Paraserianthes falcataria (L) Nielsen). Skripsi. Fakultas Pertanian Institut Pertanian Bogor. Bogor. 48 Hal.

Yuniarti, D. 2004. Pengaruh Pemberian Air Kelapa dan Dekamon dengan Waktu Pemberian yang Berbeda terhadap Pertumbuhan dan Hasil Jamur Tiram Putih (Pleurotus ostreatus). Skripsi. Universitas Muhammadiyah Malang. Malang. 